\title{
THE EFFECT OF ENTREPRENEURSHIP KNOWLEDGE ON SELF EFFICACY AND ITS IMPACT ON STUDENTS 'INTERESTS
}

\author{
Rindi Andriani ${ }^{1}$; Nizar Alam Hamdani' ${ }^{\text {; Rahyuniati Setiawan }}{ }^{3}$ \\ Universitas Garut \\ Alamat Instansi \\ rindi12andriyani@gmail.com, nizar_hamdani@uniga.ac.id,
}

\begin{abstract}
The purpose of this study is to determine the effect of Entrepreneurship Knowledge on Self Efficacy and its impact on entrepreneurial interest in students. This research uses descriptive and associative methods conducted on 68 respondents who are students of the, University of Garut. Data processing techniques used by researchers are validity, reliability, and data analysis methods using path analysis. The tool used is SPSS Software 20.0. The results of this study are entrepreneurial knowledge can affect self efficacy and have an impact on the emergence of entrepreneurial interest in students.
\end{abstract}

Keywords: Entrepreneurship Knowledge, Self Efficacy, Entrepreneurial Interest

ABSTRAK: Tujuan dari penelitian ini adalah untuk mengetahui pengaruh dari Pengetahuan Kewirausahaan terhadap Self Efficacy serta dampaknya terhadap Minat berwirausaha pada mahasiswa. Penelitian ini menggunakan metode deskriptif dan asosiatif yang dilakukan pada 68 orang responden yang merupakan mahasiswa program studi manajemen fakultas ekonomi Universitas Garut. Teknis pengolahan data yang digunakan peneliti yaitu uji validitas, uji reliabilitas, dan metode analisis data menggunakan analisis jalur (path analysis). Alat yang digunakan adalah Software SPSS 20.0. Hasil penelitian ini adalah pengetahuan kewirausahaan dapat mempengaruhi self efficacy serta memiliki dampak terhadap munculnya minat berwirausaha pada mahasiswa.

Kata Kunci : Pengetahuan Kewirausahaan, Self Efficacy, Minat berwirausaha

\section{INTRODUCTION}

Various global challenges force the mindset to change from the mindset of 'workers' to the mindset of 'creating work', this is triggered by the high competition of every workforce of young people, especially scholars in looking for work [1], [2]. This condition is inversely proportional to the availability of fewer jobs and the level of wages considered low for workers with bachelor's degrees. This condition clearly triggered the imbalance in the number of labor force printed with the percentage of employment absorption in companies and agencies [3]. The open unemployment rate based on the level of high school education in the last 3 years has increased. This condition makes entrepreneurship an opportunity that can be used as an alternative choice for students as a place for channeling skills and knowledge [4]. The younger generation, especially students in Garut Regency, has a huge opportunity to develop entrepreneurship. But unfortunately, the knowledge of students, especially the management study program at the Faculty of Economics at the University of Garut, seems to be lacking in utilizing entrepreneurship courses held by the university as a momentum to start entrepreneurship. This is illustrated through the results of a preliminary survey of researchers of 15 students related to how much their knowledge about entrepreneurship:

Researchers get information that Uniga management study program students who sit in semester 8 currently indicate lack of self efficacy stability, this is evident from their interest in entrepreneurship is very small and tends to choose to be in the comfort zone to find work.

\section{LITERATURE REVIEW}

Entrepreneurial knowledge is all information or various symptoms encountered and known by humans through the five senses and their reasoning about an effort to build a value with ability, courage, determination and creativity, and dare to take risks for opportunities towards success to open a business in various opportunities by knowing what are the factors that become the base of success towards success [5], [6]. The dimensions of entrepreneurial knowledge according to [7]are: 
a. Knowledge in actualizing business attitudes and behavior

b. Knowledge in applying leadership

c. Knowledge in planning a business

In order to apply the knowledge acquired, of course, a prospective entrepreneur needs to have a character that is strong enough and willing to face risks and make major strategic decisions to be able to run a business that is full of risk and uncertainty. This is called Self Efficacy [8].

Self Efficacy is a person's assessment of himself or the level of confidence about how much his ability in carrying out a particular task to achieve certain results [9], [10]

a. Magnitude (difficulty of the task)

b. Genarality (Area of Behavior)

c. Strength (The degree of belief or hope)

With the strengthening of knowledge by character ready to face risks and courage, the entrepreneurial interest will naturally emerge.

According to [11] Interest in entrepreneurship is one's attraction to carry out independent business activities with the courage to take risks. The dimensions of entrepreneurial interest according to [11]:

a. Personal interest (individual deposition) is a preference for certain topics.

b. Attraction (context aspect) is a psychological condition that involves being attracted to a task or entrepreneurial activity.

\section{METHOD}

To describe the knowledge of entrepreneurship, Self Efficacy and Entrepreneurial Interest in the 8th semester students of the management study program at the Faculty of Economics, University of Garut, the author uses descriptive and verification methods. In the preparation of this study, researchers conducted primary and secondary data collection. To obtain primary data, researchers used field research by conducting interviews and distributing research questionnaires. As for obtaining secondary data, researchers examined company documents such as the number of employees, the organizational structure of the company, data taken from literature studies, lectures about HR, reading documents, journals related to research variables. Researchers used the Slovin formula in determining the number of samples in the Garut University management study program semester semester 8 , so that a total sample of 68 respondents was obtained.
Furthermore respondents were given a series of questions or statements submitted in the form of questionnaires as a source of research data, while the calculation of the weight of the questionnaire value using a Likert scale

\section{RESULT AND DISCUSSION}

Table 1: Test the Validity of Entrepreneurial Knowledge Variables

\begin{tabular}{|l|c|c|c|}
\hline \multicolumn{4}{|c|}{ Item-Total Statistics } \\
\hline & $\begin{array}{c}\text { Corrected Item-Total } \\
\text { Correlation }\end{array}$ & $\begin{array}{c}\mathrm{r} \\
\text { tabel }\end{array}$ & keputusan \\
\hline Item_1 & .721 & .239 & valid \\
\hline Item_2 & .502 & .239 & valid \\
\hline Item_3 & .677 & .239 & valid \\
\hline Item_4 & .357 & .239 & valid \\
\hline Item_5 & .272 & .239 & valid \\
\hline Item_6 & .492 & .239 & valid \\
\hline Item_7 & .752 & .239 & valid \\
\hline Item_8 & .367 & .239 & valid \\
\hline Item_9 & .622 & .239 & valid \\
\hline Item_10 & .606 & .239 & valid \\
\hline Item_11 & .671 & .239 & valid \\
\hline Item_12 & .363 & .239 & valid \\
\hline Item_13 & .259 & .239 & valid \\
\hline Item_14 & .285 & .239 & valid \\
\hline
\end{tabular}

In table 1 it is known that there are 14 statement items for the entrepreneurial knowledge variable which are overall valid. Then the reliability test is performed with the following results:

Table 2: Reliability Tests for Entrepreneurship Knowledge Variables

\begin{tabular}{|l|l|}
\hline \multicolumn{2}{|l|}{ Reliability Statistics } \\
\hline Cronbach's Alpha & N of Items \\
\hline .853 & 14 \\
\hline
\end{tabular}

Based on Table 2, it is known that the variable studied has a Cronbach Alpha value of 0.853 more than the Alpha value $(\alpha)$ of 0.05 , so the measuring instrument used for the entrepreneurial knowledge variable is declared reliable. Then the validity test for the Self Efficacy variable is performed, as follows:

Table 3: Test the Validity of the Self Efficacy Variable 


\begin{tabular}{|l|c|c|c|}
\hline \multicolumn{5}{|c|}{ Item-Total Statistics } \\
\hline & $\begin{array}{c}\text { Corrected Item-Total } \\
\text { Correlation }\end{array}$ & $\begin{array}{c}r \\
\text { tabel }\end{array}$ & Keputusan \\
\hline Item_1 & .625 & .239 & Valid \\
\hline Item_2 & .528 & .239 & Valid \\
\hline Item_3 & .474 & .239 & Valid \\
\hline Item_4 & .461 & .239 & Valid \\
\hline Item_5 & .375 & .239 & Valid \\
\hline Item_6 & .571 & .239 & Valid \\
\hline Item_7 & .443 & .239 & Valid \\
\hline Item_8 & .326 & .239 & Valid \\
\hline Item_9 & .462 & .239 & Valid \\
\hline Item_10 & .467 & .239 & Valid \\
\hline Item_11 & .315 & .239 & Valid \\
\hline Item_12 & .444 & .239 & Valid \\
\hline Item_13 & .263 & .239 & Valid \\
\hline Item_14 & .400 & .239 & Valid \\
\hline Item_15 & .286 & .239 & Valid \\
\hline
\end{tabular}

In table 3 note that there are 15 statement items for the whole Self Efficacy variable declared valid. Then the reliability test is performed with the following results:

Table 4: Reliability Test Variable self efficacy

\begin{tabular}{|c|c|}
\hline \multicolumn{2}{|c|}{ Reliability Statistics } \\
\hline Cronbach's Alpha & N of Items \\
\hline .814 & 15 \\
\hline
\end{tabular}

Based on Table 4, it is known that the variable studied has a Cronbach Alpha value of 0.814 more than the Alpha value $(\alpha)$ of 0.05 , so the measuring instrument used in the form of a questionnaire is declared reliable. Then the validity test for the Entrepreneurial Interest variable is conducted, with the following results:

Table 5: Test the Validity of Entrepreneurial Interest Variables

\begin{tabular}{|l|c|c|c|}
\hline \multicolumn{4}{|c|}{ Item-Total Statistics } \\
\hline & $\begin{array}{c}\text { Corrected Item-Total } \\
\text { Correlation }\end{array}$ & $\begin{array}{c}\mathrm{r} \\
\text { tabel }\end{array}$ & Keputusan \\
\hline Item_1 & .611 & .239 & Valid \\
\hline Item_2 & .400 & .239 & Valid \\
\hline Item_3 & .485 & .239 & Valid \\
\hline Item_4 & .393 & .239 & Valid \\
\hline Item_5 & .541 & .239 & Valid \\
\hline Item_6 & .349 & .239 & Valid \\
\hline
\end{tabular}

In table 5 it is known that there are 6 statement items for the Entrepreneurial Interest variable which are declared valid overall. Then the reliability test is performed with the following results:

Table 6: Reliability Tests for Entrepreneurial Interest Variables

\begin{tabular}{|r|r|}
\hline \multicolumn{2}{|c|}{ Reliability Statistics } \\
\hline Cronbach's Alpha & N of Items \\
\hline .728 & 6 \\
\hline
\end{tabular}

Based on Table 6 it is known that the variable studied has a Cronbach Alpha value of 0.728 more than the Alpha value $(\alpha)$ of 0.05 , then the measuring instrument used in the form of a questionnaire is declared reliable.

To find out the indirect effect of entrepreneurship knowledge on Entrepreneurial Interest is determined from the sum of indirect effects through the Intervening Self Efficacy variable. The indirect effect is calculated by the sum of the direct effects of entrepreneurial knowledge on Entrepreneurial Interest with the results of the multiplication coefficient of entrepreneurial knowledge on Self Efficacy, with the coefficient of Self Efficacy on Entrepreneurial Interest. Following are the results of calculations in the previous discussion which are the answers to all the formulations of the problem in the study, then it can be illustrated in the picture below:

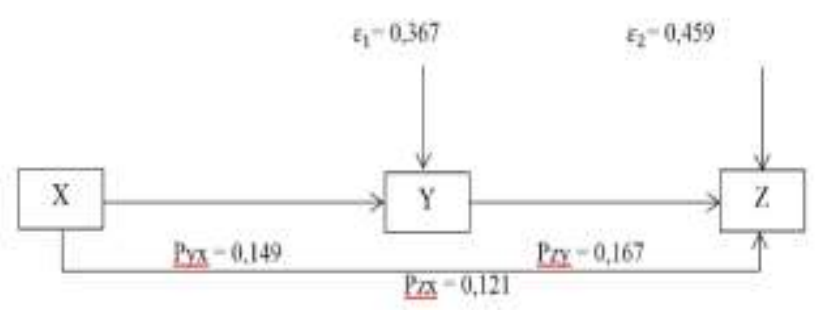

Figure 2: The Influence of Entrepreneurship Knowledge Towards Self Efficacy and Its Impact on Entrepreneurial Interest

1. Structural Equations

$$
\begin{aligned}
\mathrm{Y} & =\rho_{y x} X+\rho_{y} \varepsilon_{1} \\
& =0,149 \mathrm{X}+0,367 \varepsilon_{1} \\
\mathrm{Z} & =\rho_{z x} X+\rho_{z y} Y+\rho_{z} \varepsilon_{2} \\
& =0,121 \mathrm{X}+0,167 \mathrm{Y}+0,459 \varepsilon_{2}
\end{aligned}
$$

2. Indirect influence

$$
\begin{aligned}
& =\text { Pyx x Pzx x Pzy } \\
& =0,149 \times 0,121 \times 0,167 \\
& =0,003
\end{aligned}
$$

3. Total influence $=$ Direct Effect + Indirect Effect 


$$
\begin{aligned}
& =(0,149+0,167+0,121)+0.003 \\
& =0,440
\end{aligned}
$$

Based on these results indicate that the entrepreneurship knowledge variable on Self Efficacy is 0.149 (in percentage of $14.90 \%$ ), while Self Efficacy on Entrepreneurial Interest is 0.167 (in percentage of $16.70 \%$ ). Entrepreneurial knowledge directly towards Entrepreneurial Interest has an effect of 0.121 (in a percentage of $12.1 \%$ ) and indirectly entrepreneurial knowledge has an effect on Entrepreneurial Interest of 0.109 or $10.9 \%$. So the total effect of entrepreneurial knowledge on Self Efficay and at the same time have an impact on Entrepreneurial Interest by 0.440 or $44 \%$. This means that the allegations of researchers about the influence of entrepreneurship knowledge on Self Efficacy and the impact on Entrepreneurial Interest in 8th semester students of the Faculty of Economics management study program at the University of Garut is proven.

From these results, the results of direct influence, indirect influence, and total influence of entrepreneurship knowledge, Self Efficacy, and Entrepreneurial Interest can be clarified in the following table:

Table 6 Recapitulation of Path Analysis Test

\begin{tabular}{|l|c|c|c|}
\multicolumn{1}{|c|}{$\begin{array}{c}\text { Pengaruh Antar } \\
\text { Variabel }\end{array}$} & \multicolumn{2}{|c|}{ Pengaruh } & \multirow{2}{*}{$\begin{array}{c}\text { Total } \\
\text { Influence }\end{array}$} \\
\cline { 2 - 3 } & Direct & Indirect & \\
\hline $\begin{array}{l}\text { Knowledge of } \\
\text { entrepreneurship } \\
\text { towards Self Efficacy }\end{array}$ & 0,149 & & \\
\hline $\begin{array}{l}\text { Entrepreneurial } \\
\text { Knowledge of } \\
\text { Entrepreneurial Interest }\end{array}$ & 0,121 & 0,003 & 0,440 \\
\hline $\begin{array}{l}\text { Self Efficacy towards } \\
\text { Entrepreneurial Interest }\end{array}$ & 0,167 & & \\
\hline
\end{tabular}

Based on the results of research that has been done, it can be seen that entrepreneurial knowledge can affect self efficacy and have an impact on the emergence of entrepreneurial interest in management students of the 8th semester of the Faculty of Economics at Garut University. This is in accordance with the results of interviews conducted by researchers with respondents that they have a desire for entrepreneurship, but so far they have not been prepared with risks and guarantees for uncertainty which is always a sure thing when they do entrepreneurship. In addition, there is a lack of information on how to start entrepreneurship, amidst increasingly intense business competition and tighter business innovation [12] and [13]. Instead they feel that the knowledge about entrepreneurship obtained at the university is still felt to be lacking, so that even though there are entrepreneurship courses but that is not enough to bring up their courage in trying entrepreneurship.

\section{CONCLUSIONS}

Entrepreneurship knowledge gained by students in the 8th semester of Management Study Program at the Faculty of Economics, University of Garut has been assessed as good, in this variable the statement item with the smallest score is "I know what products are currently preferred by the community".Self Efficacy which is owned by the 8th semester students of the Management study program at the Faculty of Economics, University of Garut is good. While the statement item "I believe that being a more prospective entrepreneur" becomes the statement item with the smallest cumulative score for the Self Efficacy variable.

Entrepreneurial interest owned by the 8th semester students of the Faculty of Economics, University of Garut is good. "I am interested in doing business based on doing business to guarantee the future," is the statement item that has the smallest cumulative score for this variable.

\section{REFERENCES}

[1] S. Effendi and D. Hadiwidjojo, "The Effect Of Entrepreneurship Orientation On The Small Business Performance With Government Role As The Moderator Variable And Managerial Competence As The Mediating Variable On The Small Business of Apparel Industry In Cipulir Market, South Jakarta," IOSR J. Bus. Manag., vol. 8, no. 1, pp. 49-55, 2013.

[2] A. Hamdani, N.A dan Rhamdani, Manajemen Strategi, Edisi 1. Bandung: Karima, Bandung, 2019.

[3] M. A. Carree and A. R. Thurik, "The Impact of Entrepreneurship on Economic Growth," in International Handbook Series on Entrepreneurship, no. 2004, Netherlands: Springer Science+Business Media, 2010, pp. 557-594.

[4] N. A. Hamdani, "Building Knowledge Creation For Making Business Competition Atmosphere in SME of Batik," Manag. Sci. Lett., vol. 8, pp. 667-676, 2018, doi: 10.5267/j.msl.2018.4.024. 
[5] S. A. D. Hisrich D.Robert, Peters P.Michael, Enterpreneurship, Internatio. Mc Graw Hill, 2008.

[6] N. A. Hamdani, G. A. F. Maulani, and A. A. Muharam, "Entrepreneurial Culture in the Village of the Barbers, Garut, Indonesia," Int. J. Eng. Adv. Technol., vol. 8, no. 5C, pp. 685687, 2019, doi: 10.35940/ijeat.E1096.0585C19.

[7] L. L. Ritonga and J. Sianipar, "PROGRAM KEAHLIAN TEKNIK KONSTRUKSI KAYU SMK NEGERI 1 LUBUK PAKAM," J. Educ. BUUILDING, vol. 2, no. 2, pp. 70-76, 2016.

[8] R. Setiawan, N. Alam, and A. Solihat, "Does Entrepreneurial Knowledge Affect SelfEfficacy and Impact on Entrepreneurial Interest ?," Int. J. Innov. Creat. Chang., vol. 11, no. 12 , pp. 563-582, 2020.

[9] C. K. Marini and Si. Hamidah, "PENGARUH SELF-EFFICACY, LINGKUNGAN KELUARGA, DAN LINGKUNGAN SEKOLAH TERHADAP MINAT BERWIRAUSAHA SISWA SMK JASA BOGA," J. Pendidik. Vokasi, vol. 4, no. 2, pp. 195-207, 2014.

[10] N. A. Hamdani and A. Ramdhani, Teori Organisasi. Garut: Karima, Bandung, 2019.

[11] S. Yuwono and Partini, "PENGARUH PELATIHAN KEWIRAUSAHAAN TERHADAP TUMBUHNYA MINAT BERWIRAUSAHA," J. Penelit. Hum., vol. 9, no. 2, pp. 119-127, 2008.

[12] N. Kim-soon, A. R. Ahmad, C. W. Kiat, and H. R. Sapry, "SMES Are Embracing Innovation for Business Performance," J. Innov. Manag. Small Mediu. Enterp., vol. 1, pp. 1-17, 2017, doi: 10.5171/2017.

[13] N. A. Hamdani and G. A. F. Maulani, "The influence of E-WOM on purchase intentions in local culinary business sector," Int. J. Eng. Technol., vol. 7, no. 2.29, pp. 246-250, 2018, doi: 10.14419/ijet.v7i2.29.13325. 